\title{
The Problems and Prospects of Developing a System of Financing Innovation in Russia
}

\author{
Dmitry Yurievich Tverev ${ }^{1}$ \\ ${ }^{1}$ International Research Laboratory "Management, System Modeling and IT in Economy", ITMO University, \\ Saint-Petersburg, Russian Federation \\ Correspondence: Dmitry Yurievich Tverev, International Research Laboratory "Management, System Modeling \\ and IT in Economy", ITMO University, 49, Kronverkskiy pr, 197101, St. Petersburg, Russian Federation.
}

$\begin{array}{lc}\text { Received: March 11, } 2015 & \text { Accepted: March 30, } 2015 \quad \text { Online Published: May 22, } 2015 \\ \text { doi:10.5539/res.v7n9p140 } & \text { URL: http://dx.doi.org/10.5539/res.v7n9p140 }\end{array}$

\begin{abstract}
The rate of development of the innovative sector of the economy depends on the effective formation of a system to finance it. The choice of a base model to support innovative start-ups and the monitoring of the levels of public and private capital at every stage of development are the key issues facing countries with transitive economies. The ability to gain a foothold in the global innovation market is dependent on how these issues are tackled. However, the process of forming a financing system for innovations is associated with a number of internal and external difficulties. This article will analyze the current model of support for innovative enterprises in Russia. Internal strengths and weaknesses will be compared with external opportunities and threats. The results obtained are summarized with the opinion of the main participants in the process. Finally, a number of recommendations conducive to the further development of the system of financing innovations will be proposed.
\end{abstract}

Keywords: Innovation Lift, development finance institutions, financing innovations, SWOT analysis

\section{Introduction}

Continuous development has always been an essential factor in providing an acceptable standard of living in any country. However, with increasing competition in the world market, the requirements for the rate of local economies' development have also increased significantly. One of the key methods to increase the pace of development and improve the quality of the key sectors of the economy is innovation. The issue of innovation in countries with transitive economy is of particular relevance, since in addition to ensuring a certain quality of life within the country, they are also faced with the task of advancement on the global market and the strengthening of their position within it.

An innovation is generally understood as a new development which has been brought to and is demanded by the market, providing a qualitative or quantitative increase in the efficiency of processes or products. Thus, we can say that an innovation is a result brought to the market, which is obtained through investing in a new technology or product. Historically, industries such as healthcare, military-industrial complex and high-tech production are those with the highest demand for innovations. In recent decades, IT-technologies have also been firmly added to this list. Together, these industries provide the necessary level of national security in the country.

At the same time, the question of innovation is closely linked to the methods of its financing. To this end, countries differ in terms of the participation of public and private capital in the financing of innovative projects, the sophistication of the banking system, the stock market and the legal framework protecting the interests of developers and investors. One of the key performance indicators of the system for financing and supporting innovative projects at various stages of their implementation is the level of their final commercialization. As a rule, this figure requires careful attention in countries with transition economies, in as much as not all processes have been established, and the level of interaction between participants is not high enough to provide the required output-rate of ready solutions onto the market.

Such is this situation in Russia today, moreover, while the innovation sector of the economy is faced with ambitious objectives in terms of the rate and quality of development. In particular, an increase of the Russian share of high-tech exports to $2 \%$ of the total world market and to $10 \%$ on the world nuclear energy, shipbuilding, aerospace and aircraft markets is planned by 2020. (The strategy of innovative development of the Russian 
Federation for the period up to 2020) Increased attention to the development of innovative projects is revealing pitfalls in the current financing system. Therefore, to be able to achieve a strong position in the international innovation market, the process of financing innovation projects from the pre-seed stage to the output of the product onto the domestic or international market must be clearly set up.

\section{Method}

The systematic approach and statistical analysis form the methodological basis of the study, which allows the process of financing innovative projects to be examined both as a whole, as a single system, and within the context of the principal components.

As a basic research tool, the SWOT analysis method will be used, yielding a structured description of the current situation and the visualization of the most important external and internal environmental factors, helping to identify the main issues.

Such strategic documents as the "Strategy for innovative development of the Russian Federation for the period up to the year 2020" and the "Concept of long-term socio-economic development of the Russian Federation for the period up to the year 2020" were used in the research stage.

The main sources of information for the volumes and methods for financing innovation projects in Russia were the reports on the performance of participants in the Innovation Lift and marketing surveys carried out by such associations and professional participants as the Russian Venture Capital Association, the National Association of Business Angels, the Russian Foundation for Technological Development and the Foundation for Assistance to small Innovative Enterprises in science and Technology.

The data obtained were supplemented with information from such official sources as the Unified Information and Analytical Portal of state support for innovative business development and the Ministry of Economic Development's website.

\section{Results}

The aim of this study is to identify problem areas in the formation of a financing system for innovative projects. For this, a SWOT analysis of the current state of the financing system in the innovation sector of the Russian economy was carried out. This analysis provides a means of visualizing the key strengths and weaknesses of the current system, comparing them with favorable and unfavorable external environmental conditions and subsequently allows for the determination of the extent of their influence, having defined the most pressing challenges faced.

The analysis showed that while the growth of the funds to support innovation, in the form of both public and private capital, is growing annually, the level of commercialization of innovations remains low, which in turn results in a loss of hundreds of billions of rubles a year on the Russian innovative products market. One of the main reasons for this is the underdevelopment of the innovation financing system, which is reflected in the lack of coordination in the work of state development finance institutions within the framework of the Innovation Lift, as well as the general distrust shown by private capital towards innovative start-ups amid the low level of entrepreneurial and investment culture in general.

At the same time, in the new macroeconomic conditions and at the existing level of imperfection in the tax and legislative frameworks, for the full development of innovations the insufficient level of commercialization does not allow for private capital to be fully utilized. Attracting a large number of private investors to the financing process of innovative projects at every stage of development is becoming increasingly difficult. Furthermore, insufficient attention is paid to such strategically important activities as the export of Russian innovation into the international market and the gaining of a strong position with prospects for further expansion.

This means that the innovation financing system is acutely dependent on the federal budget, the widening gap of innovative development in the regions, the existence of threats to national security and the loss of positions in the international market with the increasing capacity gap in the country's innovative development compared to the leading countries. All these in complex can cause a systematic risk (Korableva \& Kaliullina, 2014). Moreover, the imposition of international sanctions against Russia, with all the negative impact on the economy in general, is encouraging greater attention to the development of its own innovations and improving the methods of their financing in conditions of limited access to foreign capital, from which the innovative sector of the economy only benefits.

Based on the results of the analysis, several recommendations can be made to help further develop and improve the efficiency of the innovation financing system in Russia; the most significant of these are: 
- The selection of a coordinating agency responsible for the coordination of actions of development finance institutions at different stages of financing projects;

- The unification of project selection criteria and application forms for funding;

- The partial reorientation of public investors from the preferential allocation of grants to non-gratuitous funding;

- The development of criteria for the regular performance evaluation of development finance institutions.

In drawing up the list of recommendations, the views of direct participants in the process were taken into account, which improves the relevance of the proposed measures and indicates their practicality. The implementation of these recommendations will help to improve the work of the Innovation Lift which ultimately will more effectively move projects through the stages of development to their IPO. Meeting targets in terms of market output volumes of innovative products and services will enhance the competitiveness of the Russian economy on an international scale.

\section{Discussion}

The system of financing innovation improvement problematics is discussed both in government and business community. Dmitry Medvedev attends largest thematic forums, where he shares his point of view on the subject and listens to participants. Moscow International Forum for Innovative Development "Open Innovations" became one of the main platforms and in his welcoming speech Prime Minister of Russia summarized government activity results in innovation projects supporting and infrastructure construction.

Saint-Petersburg International Innovation Forum becomes more and more popular too. Innovation business representatives bring up the thorniest questions. For example, Alexei Kovsh, one of the founders of Optogan JSC, a company working in the production of LED products, noted a lack of state activity in creating demand for innovative products and raised the question of the effectiveness of the Innovation Lift (Saint-Petersburg International Innovation Forum, 2013).

Every year efficiency of development finance institutions is given more and more attention. Michael Gorski, Senior Advisor of RVC, in his article for Forbes magazine in 2013 "How to Repair the Innovation Lift" called into question the current system of support for innovative start-ups, noting that public corporations always fall short in terms of efficiency compared to private companies and are not focused on the needs of the innovation consumer. (Gorski, 2013) Also, in 2013, Irina Dezhina, Section Head at the Institute of World Economy and International Relations, in her article for "Troitsky Variant" entitled "Development finance institutions: what is known about their effectiveness?", raised the question of assessing the effectiveness of development finance institutions (Dezhina, 2013).

In 2014 problematics description became more concrete because of last few years experience. It should be noted that experts recognized the importance of understanding the life cycle of innovation and the ability to adjust the funding cycle to it accordingly (Udachina, 2014).

Participants in the Innovation Lift and representatives of organizations close to it themselves confirm the presence of failures to finance projects in their advancement through the system. For example, as part of the "How to bridge the gaps in financing projects at various stages" panel discussion, it was noted that public investors continue to focus on the process rather than the result, and it was proposed to re-orient them from awarding grants to anon-gratuitous financing system in order to improve the efficiency. The director of the Department for Organization Research Complex at the Skolkovo Foundation, Leonid Vodovatov, noted that funding should correspond to the innovation cycle and to the quality of entrepreneurs at every stage of development, from the idea, through the formation of the company and in its future development (Open Innovations Forum, 2014).

So let's look to the system closely. The innovation financing system as a whole in the Russian Federation was formed in 2010, when an agreement was signed on cooperation in the field of continuous funding for innovative projects of small and medium-sized enterprises at all stages of the innovation cycle. The proposed scheme was called the Innovation Lift, and its goal was to create an effective mechanism for the exchange of information and support of perspective innovation projects through their sequential transfer between relevant development finance institutions.

Under the proposed model, action is carried out in the following areas:

- The search for the most promising projects in terms of implementation;

- The submission of projects for consideration to other parties in agreement; 
- The provision of funding at all stages of their implementation;

- The attraction of private investment to projects supported by development finance institutions;

- The development of common approaches to the selection, assessment, structuring and implementation of innovative projects.

The main parties involved in the agreement are:

- State corporation, the Bank for Development and Foreign Economic Affairs (Vnesheconombank)—via subsidiary banks, the main of which is SME Bank OJSC;

- State corporation, Russian Nanotechnologies Corporation (RUSNANO);

- The Russian Venture Company JSC (RVC);

- The Foundation for Assistance to Small Innovative Enterprises in Science and Technology (FASIE);

- Moscow Interbank Currency Exchange JSC (MICEX);

- The Russian Venture Capital Association (RVCA);

- The Federal Agency for Youth Affairs (Rosmolodezh).

To date, the list of development finance institutions also includes the Russian Foundation for Basic Research (RFBR), Russian Foundation for Technological Development (RFTD), the Skolkovo Foundation, the VEB-innovation Foundation, as well as many regional organizations, which in some way contribute to the development of innovative enterprises. It is worth noting, that for the Russian domestic market, the development of innovative projects has become particularly important since the introduction in 2014 of international sanctions and restrictions to the funding major Russian state-owned banks and corporations abroad. In addition, funding from international financial institutions has also been limited. Therefore, in the interest of enhancing national security, as well as providing domestic producers and consumers with the volumes of innovations necessary for quality development, the state has focused its attention on fully supporting the innovation economy. Thus, the further development of the Innovation Lift model has found popularity, and it is gradually beginning to yield results.

When considering the participation of major development finance institutions in supporting innovative developments, it should be noted that irregular reporting and the lack of a standardized form of reporting for participants in the process greatly complicates any assessment of their performance.

The "ground floor" of the "lift" was formed in 1994, the Foundation for Assistance to Small Innovative Enterprises in the scientific and technical sphere. Its task is to provide favorable conditions for organizing the flow of the most promising projects ready for the continued support by other participants in the process. Thus, the foundation provides both financial support and information to small-sized innovative enterprises at the pre-seed and the seed stages. From 2012 to 2013, the foundation reviewed over 7,000 applications for participation in various competitions and programs. As part of the financing of innovative projects at the research and development stage, more than 6,000 contracts, totaling approximately 7.3 billion rubles, were made from the federal budget to fund programs and competitions (Reports of the Foundation for Assistance to Small Innovative Enterprises in science and technology, 2012-2013). In addition, the foundation is responsible for the examination of incoming applications and the subsequent selection of the most promising projects, so that they can receive the necessary financing for the next phases. Further, the sources of funding for the winning projects are both budget and off-budget investment. As a result, over 100 companies received further support from other development finance institutions during this period.

To date, the most prominent role in promoting innovative start-ups is played by the Foundation for the Development and Commercialization of New Technologies, Skolkovo, which joined the list of development finance institutions in 2011. The mission of the Foundation became the creation of a self-governing, self-sustaining ecosystem, which would facilitate the development of entrepreneurship and increase the volume of various studies, eventually leading to the emergence of successful companies on the international market. As part of the center's work, scientists and engineers, together with the participants of educational projects and business representatives, have begun work on competitive world-class knowledge-based developments in priority areas such as: energy efficiency and conservation, strategic computer technologies and software, as well as telecommunications, and biomedical, nuclear, and space technologies. In terms of funding innovation projects, residency at "Skolkovo" has become one of the most popular tools for further support for start-up companies under the concept of the Innovation Lift. From 2012 to 2013, the foundation approved the allocation of 145 grants, totaling approximately 4.3 billion rubles (Report on the Work of Skolkovo, 2013). However, only 19 
Grants, totaling approximately 503.5 million rubles, were approved in the first half of 2014 (Report on the Work of Skolkovo, 1st quarter of 2014).

Having reached the seed stage, innovative companies find themselves in dire need of venture capital. The Russian Venture Company OJSC (RVC) is a state fund of funds and it is considered to be one of the key tools for forming the national innovation system. The company is faced with two strategic objectives: promoting the process of creating a fully fledged Russian private venture capital industry, and the increasing the financial resources of venture capital funds. The work is aimed at creating a service infrastructure for the venture capital market players, increasing the transparency of funds, and optimizing the legal framework. In order to improve the overall competitiveness of the domestic innovation sector on an international scale, RVC, together with private investors, has created 18 venture capital funds, the total volume of which isover 25.9 billion rubles; of this, the share of RVC is more than 16.1 billion rubles. Priority areas for investment, as identified by the President of the Russian Federation are:

- Security and counter-terrorism;

- Biotechnology and medical technology;

- Nanosystems;

- Information and telecommunication systems;

- Management of natural resources;

- Transport, aviation and space systems;

- Energy efficiency and conservation.

From 2012 to 2013, RVC, and funds set up with its participation, financed 65 innovative companies, totaling approximately 5.2 billion rubles (Annual reports of RVC, 2012-2013), while in 2014, 166 companies were financed, totaling over14.8 billion rubles (RVC, 2015).

However, looking at the venture capital market as a whole, data from the Russian Venture Capital Association shows the number of operating funds rose from 155 in 2008 to 337 in 2014. As of September 2014, the total volume of their capital amounted to about 960 billion rubles. Of this, approximately 784 billion rubles was accounted for by 116 private equity funds and only 176 billion rubles was accounted for by 221 venture funds. The vast majority of funds are located in the Central Federal District. (Analytical report on the review of the market for Russian venture funds, I-III quarters 2014) From 2012 to 2013, 414 investment deals with a known volume were registered in the market, and the total volume of capital directed towards Russian companies amounted to approximately 220 billion rubles. (Market surveys of equity and venture capital in Russia, 2012-2013) However, over a 9-month period in 2014, 170 transactions totaling only around 24 billion rubles were made (Analytical report on the review of the market for Russian venture funds, I-III quarters 2014).

More prominent in recent years has been the financing of innovative initiatives in the early stages by private equity investments in the form of business angels, who are not formally included in the Innovation Lift model, but play an important role in the process of innovation support as a whole. The term "business angel' is used to describe private investors, investing in innovation projects for a period of 3 to 7 years without securities and guarantees in exchange for a stake in the company. Thus, they invest their own available funds, in contrast to venture capital funds, which manager the monetary funds of third parties. It is generally assumed that this type of investor is interested in investing in the early stages of an innovative project's development, at the seed and initial stages. It is after this that venture capital, and then direct investments are brought in. The main income they receive is from the subsequent sale of their shares at a cost much higher than the initial investment. Such sales are usually made to a specific strategic investor, the founder of the company themselves, or on the stock market. However, exiting a project often involves a number of challenges and risks for both sides due to the presence of a number of unresolved structural problems, which include:

- The low efficiency of negotiations with the founders of innovative projects;

- The virtual absence of established procedures and criteria for assessing risk and determining the optimal amount of potential investments;

- The lack of awareness about the activities of business angels and successful projects due to the absence effective methods of communication between market participants;

- The inability to calculate the efficiency of a business angel withdrawing from a project due to the imperfection of patent laws and the relative narrowness of the stock market, which significantly reduces the number of 
potential buyers of the business.

Nevertheless, despite all the risks involved, this type of investment is considered one of the most profitable types of business, since a successful project may provide the investor with a profit of more than $70 \%$ per annum. However, even with a sufficiently high potential profitability, the National Association of Business Angels in Russia only includes around 3,000 business angels. (NABA, 2015) From 2012 to 2013, these business Angels funded approximately 130 early-stage projects totaling around 4.5 billion rubles ("The annual market research of business angel investments", 2013). However, unlike the previous years, in the middle of 2014 there was a marked decline in investment and in a 10-month period of the year only 47 projects were funded, totally approximately 961 million rubles. ("The annual market research of business angel investments", 2014) Analysts attribute this to increased risk caused by general economic and political instability which triggered the transition of some of the most active participants to other classes of investors.

Individual attention should also be paid to the fact that the Russian banking system, as a whole, is not focused on financing innovative projects. Several of the most important reasons preventing commercial banks from fully integrating themselves into the process of supporting the development of innovation can be singled out. One of the main reasons is the historically conservative attitude of banks to potential borrowers, which from the outset imposes strict requirements concerning reputation, financial reporting, the availability of securities, and the intended use of the borrowed funds. In addition, banks do not receive incentives, in the form of special tax rates, when increasing their loan portfolio with innovative projects, and a system of risk sharing between commercial banks and the state has not yet been established. The combination of these factors, strongly delays the banks' decision-making process, and in the case of innovative projects with their short existence periods, the absence of securities and their uncertain commercialization prospects, this leads to the impossibility of their funding in principle.

Therefore, to date, the work of financing innovation is mainly concentrated in the hands of large state-owned banks, the key of which is Vnesheconombank, which acts as a development bank and operates nationwide through a series of subsidiary banks. Funding is provided in the form of loans and equity positions in companies. As a public corporation, the bank does not compete with commercial lenders and only finances the most complex, long-term, and capital-intensive projects which require minimum of1 billion rubles.

Available information currently shows that Vnesheconombank is simultaneously participating in more than 66 different projects aimed at promoting innovation. The projects cover 21 industry, infrastructure, and the defense industry. Innovative projects constitute approximately a 34.5\% share of the bank's loan portfolio. In July 2014, the Bank was involved in the financing of 26 innovative projects worth about 199 billion rubles, of which the bank's sharewas approximately 169.9 billion rubles; (VEB, 2015) and from 2012 to 2013 the bank approved funding for 24 projects worth 368.5 billion rubles of which the bank's share was approximately 157.6 billion rubles (Reports on sustainable development of the Vnesheconombank Group, 2012-2013). However, attention should be paid to the imposition of the international sanctions in 2014, which imposed a ban on the funding of the largest state-owned banks and corporations abroad, which include Vnesheconombank. That, in turn, affects the adjustment of originally projected targets.

In order to create mechanisms for the release of innovative companies onto the market and promote the timely implementation of the change of investors in 2009, a new stock exchange segment "Innovation and Investment Market" was set up by the Moscow Interbank Currency Exchange group in conjunction with the Nanotechnologies group, which became the last floor of the Innovation Lift. Its tasks include:

- The organization of cooperation between stakeholders at all stages; from funding in the early stages to their release directly onto the stock market;

- The establishment of a transparent mechanism for attracting funding, first and foremost for small and medium-sized businesses engaged in innovative projects;

- The development of the public-private partnership concept.

According to stock exchange estimates, small-sized innovative companies with a market capitalization of 300 million rubles and a revenue of 150 million rubles have the highest potential for a successful IPO. To date, more than 40 securities are listed in the Innovation and Investment Market. The total volume of trade in the first 10 months of 2014 was estimated at 300 billion rubles, and the total capitalization of the sector was about 130 billion rubles (TechUp, 2014). The main negative point of the public offering is considered to be the underestimation of companies because of the weakness of the market, as a result of which the level of capitalization based on real business and the value of traded securities may differ by several times. 
In order to identify an objective situation in the sphere of financing innovation, a SWOT analysis study was conducted by the authors of this article. The purpose of this analysis is to identify the priority areas for strategic development in the innovation financing system, and possible problems which could occur in its development. This type of research allows problems, the solutions to which will subsequently be implemented by means of the selection and implementation of strategic alternatives, to be identified and clearly defined.

The analysis begins with the definition of basic concepts.

The opportunities of the external environment - these are the events or trends that may contribute to the further development and strengthening of effective models for financing innovation. Using macroeconomic indicators, foreign and domestic news, as well as the aforementioned information in order to conduct the analysis, the following opportunities of the environment have been identified:

1) The adoption of the state "Strategies for the Innovative Development of the Russian Federation for the Period up to the Year 2020", which defined the objectives, priorities and instruments of state innovation policy. This policy also set long-term objectives for the subjects of innovation, funding for basic and applied science, as well as increasing the efficiency in commercializing developments. This signifies the critical importance to the state of increasing the pace of innovation development.

2) The presence of private investors interested in obtaining potentially high profits from participation in venture capital projects, which illustrates the positive dynamics of the development of the venture financing market in Russia, as well as a gradual change in the ratio of private and public capital on the market in favor of private investors.

3) Regionally specific needs for innovation in the Russian Federation, due to historical differences in the level and rate of development of different regions, as well as part of the cluster model of innovative development. However, despite the fact that some regions are trying to promote a favorable environment for innovation, there is not enough active exchange of best practices between regions.

4) The need for the development of the internal innovation market in the conditions since the introduction of international sanctions against Russia, in order to enhance national security. It is the reason for the significant narrowing of the possibility of obtaining funding from largest state-owned banks and corporations, which have lost the opportunity to find funding abroad, along with impaired interaction with foreign suppliers of high-tech products, which affect all spheres of innovation from biotechnology to information and communication technologies. Thus, maintaining the required pace of innovation development in all sectors is not possible without the development of the internal market.

5) The export of innovations on the international market as one of the strategic initiatives of the state and an important aspect in cooperation with partner countries.

The threats of the external environment- these are events or trends that weaken the existing model of financing innovation or reduce the potential for development. In this analysis the following threats from the external environment were identified:

1) The instability of tax legislation in the Russian Federation and the lack of a benchmark to encourage commercial banks to broaden their innovative-project loan portfolios.

2) A lack of development in terms of the legal framework for the protection of interests of participants in innovation projects, which is reflected in the fairly high lack of confidence private investors have in innovative projects. Therefore, despite the positive dynamics of the venture capital market, the level of development is not yet sufficient to ensure the uninterrupted financing of innovative projects at all stages of their life cycle.

3) The lack of international funding for the largest institutional investors and public corporations due to the imposition of sanctions against Russia.

4) The lack of interest on the part of foreign investors in an independent innovative Russia due to the loss of the potential market for high-tech products along with the increase in competition.

5) The lack of development of the stock market, which limits the possibility of growth in the number of full and timely exits of investors from projects. The extremely low number of innovative companies issuing IPOs, leads to the fact that the company founders have to find specific strategic investors, which adversely affects the pace of the project. In addition, there is no possibility for timely and quick changes of investors at different stages of the project life cycle.

The strengths of the innovation financing system are existing skills and competencies which allow for the use of new favorable trends of the external environment, and avoidance of the adverse ones. Thus, using this 
information the following strengths can be seen:

1) The distribution of risks between the state and private capital due to the formation of a system of state development finance institutions on the one hand, and the formation of a venture capital market on the other.

2) Targeted financing of projects due to a complete shift in priorities from financing major public research institutions to financing specific developments at different stages of development.

3) The adoption of the Innovation Lift has provided a continuous innovation cycle, as developments, under the constant supervision of development finance institutions, have the opportunity to receive targeted financing when changing stages.

4) An increase in the share of private sector participation in the financing of innovation, which corresponds to the global trend, has become possible, on the one hand, due to the development of the venture capital market, and on the other hand, the gradually decreasing degree of mistrust in the innovative segment of the market from private investors, through better business planning.

5) A significant increase in the number of venture capital funds and private equity funds associated with the rapid development of the venture capital market in general, and the actions of the State to promote this area of innovation finance.

As weaknesses, the analysis refers to the lack of certain skills, reducing the overall efficiency of the system. Thus, the analysis identified the following weaknesses:

1) A significant decrease in the proportion of foreign capital participating in the financing of innovation due to the introduction of international sanctions against Russia, and a general lack of interest on the part of foreign capital in enhancing competition in the Russian market.

2) The historical priority of developing major innovative projects against the background of low confidence of private investors in the innovation sector, limiting the financing of small and medium-sized innovative enterprises.

3) The low level of project commercialization due to existing gaps in moving from the R\&D stage to the product launch, since far from all projects fall within the realms of the Innovation Lift.

4) Difficulties with the carrying out the exit of investors at the final stage of financing innovation due to the inadequate development of the stock market;

5) The isolated, non-systemic participation of commercial banks in financing innovation due to lack of securities and risk assessment procedures for innovative start-ups, as well as the lack of incentives from the state. The main player is Vnesheconombank, which works through a system of subsidiary banks.

The comparative matrix (Appendix 1) allows us to estimate the degree of coincidences in strengths and weaknesses and opportunities and threats using a simple scale of "+", "0" and "-." symbols.

Possible types of conclusions, divided into zones, are presented in the table below:

Table 1. SWOT analysis model

\begin{tabular}{lll}
\hline & Opportunities & Threats \\
\cline { 2 - 3 } Strengths & Growth & Protection \\
Weaknesses & Improvement & Challenges \\
\hline
\end{tabular}

In addition, the values obtained for the purpose of further calculation are taken modulo:

Table 2. Strengths and Weaknesses

\begin{tabular}{lll}
\hline & Opportunities & Threats \\
\hline Strengths & 16 & 3 \\
Weaknesses & 15 & 15 \\
\hline
\end{tabular}

Diagonal "Growth/Problems": $|16|-|15|=|1|$

Diagonal "Improvement/Protection": $|15|-|3|=|12|$ 
The largest difference in the values indicates the diagonal, which should be considered in the formulation of the main problems and the development of further development strategy. Moreover, for further development within the diagonals the area with the highest value is selected. According to the results of the analysis the area requiring close attention is "Improvement". In addition, the total amount of points in rows and columns with mutually neutralizing "+" and "-" indicates the priority of controls of various factors in the formation of a strategy for further development (see Appendix1). As a result, the most acute problem being faced is the currently existing low levels of commercialization of innovative projects, which under the imposed of international sanctions and the existing level of imperfection of the tax and legal framework, does not allow full advantage of emerging opportunities to be taken.

\section{Conclusion}

Based on the above information it is clear that, despite the increased role of private capital in the development of innovation, the state remains a key player in the market of venture financing. As noted at the "Open Innovation" forum, for the period from 2007 to 2013 a total of around 13 thousand innovative projects received support from the state totaling approximately 700 billion rubles. An additional sum, in the region of 135 billion rubles, was invested into various research and worked towards broadening the process of cooperation between educational institutions and industrial enterprises. In various parts of the country 25 technology parks and innovative regional clusters were created (Politov \& Prasolov, 2014). However, comparative analysis and objective assessment of the effectiveness of state development finance institutions are difficult due to the fact that a unified system of criteria and standardized reporting form has still not been developed. Any further research is complicated by the absence of detailed reports from a number of players.

The lack of long-term private capital in the market leads to the dominance of public funding, particularly in the pre-seed and seed stages. However, companies have to put together large sets of documents and the deadlines for the investment decision-making process are often delayed, as a significant part of public investors are still more focused on the process itself rather than the result. Furthermore, the application forms in different development finance institutions differ significantly. Funds, in the form of grants, are allocated by state investors, often without providing post-investment after-care services; however, the investors try to finance as many projects as possible by reducing the size of the grants. The result of this underfunding is that companies initially did not have time to reach the necessary result which, in turn, makes it impossible to attract investors at the next stage. As a result, the number of successfully completed projects is decreasing. According to the assessment of the Russian Foundation of Technological Development (RFTD), the backlog of demand from technology companies for loans to conduct $\mathrm{R} \& \mathrm{D}$ is about 20-30 billion rubles per annum, which corresponds to the shortfall of innovative products in the market of around 150-200 billion rubles per annum (Report "Strategic Planning. The role and place of development finance institutions in the technological development of Russia", 2014).

Thus, most experts recognize one of the main reasons for the low level of commercialization of innovative projects as the de facto underfunding of these projects at different stages due to alack of coordination of state development finance institutions. Therefore, the main recommendations for the further development of the innovation financing system include:

1) The allocation of an organization coordinator, responsible for the coordination of the work of development finance institutions at different stages of project financing;

2) The unification of project selection criteria, application forms for funding, and sets of documents required by different development finance institutions in order to avoid the duplication of documents and, as a consequence, delays in the financing process;

3) The introduction of tax incentives for small and medium-sized innovative enterprises, including those outside the industrial parks;

4) The comprehensive protection of the interests of all parties involved in the development of innovations, ensuring the proper fulfillment of signed contracts, as well as the formation of an effective patent infrastructure and the development of the intellectual property rights market;

5) The partial reorientation of public investors from the preferential allocation of grants to non-gratuitous forms of investment financing;

6) The development of criteria for regularly evaluating the performance of development finance institutions;

7) Encouraging the banking system as a whole to participate in the financing of innovation by providing special tax conditions to banks actively financing innovative enterprises, which will cover the high risks of uncertainties and lack of required securities; 
8) Ensuring the timely and effective change of investors, depending on the stage of the innovation project, along with the optimization of the conditions for small and medium-sized innovative companies to issue their ipo by further developing the stock market and the improving tax legislation;

9) The reduction of the innovative industry's dependence on large projects implemented by public research institutions, dependent on funding by large institutional investors, and subject to international sanctions, by increasing the number of small and medium-sized innovative enterprises, as well as further developing the venture capital market;

10) The more in-depth study of the life cycle of innovations in the industry depending on their application;

11) Support not only for well-established companies, but also for specific inventors at the initial stage.

\section{References}

Analytical report on the review of the market for Russian venture funds I-III quarters. (2014). Retrieved from http://www.rusventure.ru/ru/programm/analytics/docs/RVCA_yearbook_2014_Russian_PE_and_VC_mark et_review_I-III-2014_ru.pdf

Annual report of RVC for 2012. (2012). Retrieved from http://www.rusventure.ru/ru/programm/analytics/docs/preview_RVC2012.pdf

Annual report of RVC for 2013. (2013). Retrieved from $\mathrm{http} / / /$ www.rusventure.ru/ru/programm/analytics/docs/Report_RVC2013.pdf

Dezhina, I. (2013). Development finance institutions: What is known about their effectiveness? Troitsky Variant, 126. Retrieved from http://trv-science.ru/2013/04/09/instituty-razvitiya-chto-izvestno-ob-ikh-ehffektivnosti/

Gorski, M. (2013). How to Repair the Innovation Lift. Forbes. Retrieved from http://www.forbes.ru/mneniya-column/idei/239647-kak-otremontirovat-innovatsionnyi-lift

Innovation Lift will save the most responsible ones. (2013). Saint-Petersburg International Innovation Forum. Retrieved from http://forum.spbinno.ru/i2011/press_center/news/e2858/

Korableva, O., \& Kaliullina, O. (2014). The Formation of a Single Legal Space as a Prerequisite for Overcoming Systemic Risk. Asian Social Science, 10(21). http://dx.doi.org/10.5539/ass.v10n21p256

Market survey of equity and venture capital in Russia in 2012. (2012). Retrieved from http://www.rvca.ru/rus/resource/library/rvca-yearbook/\#download

Market survey of equity and venture capital in Russia in 2013. (2013). Retrieved from http://www.rvca.ru/rus/resource/library/rvca-yearbook/\#download

Moscow International Forum for Innovative Development "Open Innovations". (2014). Retrieved from http://www.forinnovations.ru/

NABA. (2015). http://rusangels.ru/naba/investors/business-angels-investment/

Politov, Y., \& Prasolov, O. (2014). Medvedev: Innovation development remains priority for Russia. Retrieved from http://www.rg.ru/2014/10/14/innovacii-site-anons.html

Report "Strategic Planning: The role and place of development finance institutions in the technological development of Russia". (2014). Retrieved from http://www.slideshare.net/RFTRpresents?utm_campaign= profiletracking\&utm_medium $=$ sssite\&utm_source=ssslideview

Report of the Foundation for Assistance to Small Innovative Enterprises in science and technology for 2012. (2012). Retrieved from http://www.fasie.ru/media/files/2012go.pdf

Report of the Foundation for Assistance to Small Innovative Enterprises in science and technology for 2013. (2013). Retrieved from http://www.fasie.ru/media/files/Godovoy\%20otchet\%202013\%281\%29.pdf

Report on sustainable development of the Vnesheconombank Group. (2012). Retrieved from http://www.veb.ru/common/upload/files/veb/reports/rsd/rsd_12_rus.pdf

Report on sustainable development of the Vnesheconombank Group. (2013) Retrieved from http://vneshbank.ru/common/upload/files/veb/reports/rsd/rsd_13_rus.pdf

Report on the Work of Skolkovo for 2013. (2013). Retrieved from http://sk.ru/foundation/results/b/reports/archive/2014/10/13/rezultaty-raboty-za-dekabr-2013-goda.aspx 
Report on the Work of Skolkovo for the 1st quarter of 2014. (2014). Retrieved from http://sk.ru/foundation/results/b/reports/archive/2014/10/13/rezultaty-raboty-za-vtoroy-kvartal-2014-goda.a $\operatorname{spx}$

$R V C$. (2015). http://www.rusventure.ru/ru/company/brief/

TechUp. (2014). http://www.ratingtechup.ru/news/871/

“The annual market research of business angel investments” for 2013. (2013). Atom Partners LLC. Retrieved from http://www.rusventure.ru/ru/programm/analytics/docs/201312_angel_investments.pdf

“The annual market research of business angel investments" for 2014. (2014). Atom Partners LLC. Retrieved from

http://www.rusventure.ru/ru/programm/analytics/docs/201412_market_research_angel_investments.pdf

Udachina, M. (2014). The strategy of innovative development of the Russian Federation for the period up to 2020. The life cycle of innovation: Role and efficiency of development institutes. Research and Development Financial Institute. Retrieved from http://www.nifi.ru/en/rss/416-konferenciya-2410.html

VEB. (2015). http://www.veb.ru/strategy/innovation/

\section{Appendix}

Appendix A.

\begin{tabular}{|c|c|c|c|c|c|c|c|c|c|c|c|c|}
\hline \multirow[b]{2}{*}{ External } & \multirow[t]{2}{*}{ Internal } & \multicolumn{5}{|c|}{ Opportunities } & \multicolumn{5}{|c|}{ Threats } & \multirow[t]{2}{*}{ Total } \\
\hline & & $\begin{array}{l}\text { Strategy } \\
2020\end{array}$ & $\begin{array}{l}\text { Interest of domestic } \\
\text { private investors in } \\
\text { receiving high profits } \\
\text { from participation in } \\
\text { venture projects }\end{array}$ & $\begin{array}{c}\text { Regional differences in } \\
\text { innovational demand }\end{array}$ & $\begin{array}{c}\text { Increased } \\
\text { national security }\end{array}$ & $\begin{array}{c}\text { The export of } \\
\text { innovation onto } \\
\text { the international } \\
\text { market }\end{array}$ & $\begin{array}{l}\text { Unstable tax } \\
\text { legislation }\end{array}$ & $\begin{array}{l}\text { Underdeveloped } \\
\text { legal base for } \\
\text { protecting the } \\
\text { interests of } \\
\text { participants }\end{array}$ & \begin{tabular}{|c|} 
The lack of international \\
finance for large \\
institutional investors \\
due to sanctions
\end{tabular} & $\begin{array}{l}\text { Disinterest of foreign } \\
\text { investors in an } \\
\text { independent innovative } \\
\text { Russia }\end{array}$ & \begin{tabular}{|c|} 
The \\
underdevelopment \\
of the stock market
\end{tabular} & \\
\hline \multirow{5}{*}{$\begin{array}{l}\mathrm{s} \\
\mathrm{t} \\
\mathrm{r} \\
\mathrm{e} \\
\mathrm{n} \\
\mathrm{g} \\
\mathrm{t} \\
\mathrm{h} \\
\mathrm{s}\end{array}$} & 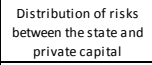 & & + & + & & & 0 & 0 & - & & & 1 \\
\hline & $\begin{array}{c}\text { Targeted financing of } \\
\text { projects }\end{array}$ & & + & & + & + & & - & & & & 2 \\
\hline & $\begin{array}{l}\text { The Innovation Lift as a } \\
\text { means of providing } \\
\text { continuity in the } \\
\text { innovation cycle }\end{array}$ & + & + & + & + & + & 0 & 0 & - & 0 & & 4 \\
\hline & $\begin{array}{l}\text { The increasing share of } \\
\text { private venture capital }\end{array}$ & + & + & + & & & 0 & 0 & & 0 & & 3 \\
\hline & $\begin{array}{l}\text { The significant increase } \\
\text { of venture funds and } \\
\text { direct capital funds }\end{array}$ & + & + & + & & & & & 0 & 0 & & 3 \\
\hline \multirow{5}{*}{$\begin{array}{c}\text { w } \\
\text { e } \\
\text { a } \\
\text { k } \\
\text { n } \\
\text { e } \\
\text { s } \\
\text { s } \\
\text { e } \\
\text { s }\end{array}$} & $\begin{array}{l}\text { The significant decrease } \\
\text { of foreign capital }\end{array}$ & 0 & 0 & - & & & - & - & - & - & & -5 \\
\hline & $\begin{array}{c}\text { The priority of } \\
\text { developing large } \\
\text { projects }\end{array}$ & & - & - & - & - & & & - & 0 & & -5 \\
\hline & $\begin{array}{c}\text { Low commercialization } \\
\text { level of projects }\end{array}$ & 0 & - & - & - & - & - & - & - & - & & -8 \\
\hline & \begin{tabular}{|c|c|}
$\begin{array}{c}\text { Complications with } \\
\text { investor 'exits' }\end{array}$ \\
\end{tabular} & & - & & - & - & - & - & & & - & -6 \\
\hline & $\begin{array}{c}\text { The non-systemic } \\
\text { participation of banks } \\
\text { in innovation finance }\end{array}$ & & & - & - & - & - & - & - & & & -6 \\
\hline Total & & 3 & 2 & 0 & -2 & -2 & -4 & -5 & -6 & -2 & -1 & \\
\hline
\end{tabular}

\section{Copyrights}

Copyright for this article is retained by the author(s), with first publication rights granted to the journal.

This is an open-access article distributed under the terms and conditions of the Creative Commons Attribution license (http://creativecommons.org/licenses/by/3.0/). 